DOI: 10.20472/IAC.2017.33.077

EDA YILMAZ

Hacettepe University, Turkey

\title{
THE EFFECT OF FINANCIAL AUTONOMY IN TURKISH PUBLIC HIGHER EDUCATION FINANCING SYSTEM
}

\begin{abstract}
:
Higher education institutions (HEIs) are aiming to be by far autonomous regarding rising demand for higher education in recent years. Financial autonomy is one of the momentous determinants in accordance with tuition fee and loans. Managing resources independently would allow universities to reach their strategic aims more successfully. Many criteria are allowed for considering financial autonomy of university and among these criteria determination of tuition fee freely by a university or by an external authority is an important decision to finance public higher education. While tuition fee approach derives from financing higher education by public resources, HEls would be the authority to decide the amount of it between upper and lower limits settled on by the external authority. Further to that, loan opportunities to pay the fees should be taken into account for especially poor-background students which affect the attendance level. These loan opportunities may be provided either by the government or private sector. In this study how tuition fee is decided due to financial autonomy in Turkey and which loan options are available to students will be examined in comparison with Australia to show the effect transparently.
\end{abstract}

\section{Keywords:}

Higher education finance, autonomy. 